\title{
backstory
}

\section{Saltwater surprise}

\section{Murray Gingras and colleagues examined lagoon goo for signs of life from the comfort of a moonlit rooftop in the Caribbean.}

What was the objective of the work? Following on from our earlier findings that aquatic organisms reside below microbial mats in boreal, freshwater lakes, we wanted to see whether animals can thrive in a similar setting in high-salinity lagoons. These lagoons serve as analogues for the sea floor in the Ediacaran period, 635-542 million years ago, which was dominated by photosynthetic microbial mats. By studying modern-day lagoons, we hoped to understand how animals evolved during the Ediacaran period.

Why did you choose this particular location for the work?

The sedimentology of the Los Roques lagoons in Venezuela had already been characterized, allowing us to identify microbially influenced lagoon deposits throughout the archipelago before our arrival. Plus, the archipelago has a reputation for pristine sedimentary settings, which is desirable if one wants to characterize natural modern settings to understand the rock record; human influence can markedly alter sediment, animal and biomat distributions. Finally, one of our co-authors is Venezuelan, and knew the locale.

\section{What sort of samples were you} looking for?

We collected water, sediment and microbial mat samples from the lagoons. In the evening, we transported the samples back to a makeshift laboratory on the rooftop of our 'posada', where we measured oxygen and hydrogen sulphide concentrations to assess the importance of photosynthetic versus sulphate-reducing microbial processes. As the sun set, we watched from the comfort our cool, moonlit rooftop as oxygen production in the mats waned, and sulphide swamped the samples.

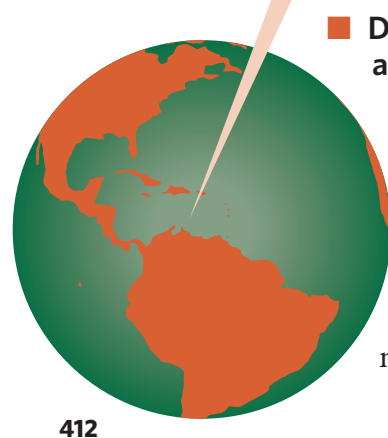

Did you encounter any difficulties?

Underwater samples were difficult to procure. Some sections of the lagoon floor were covered with as much as $50 \mathrm{~cm}$

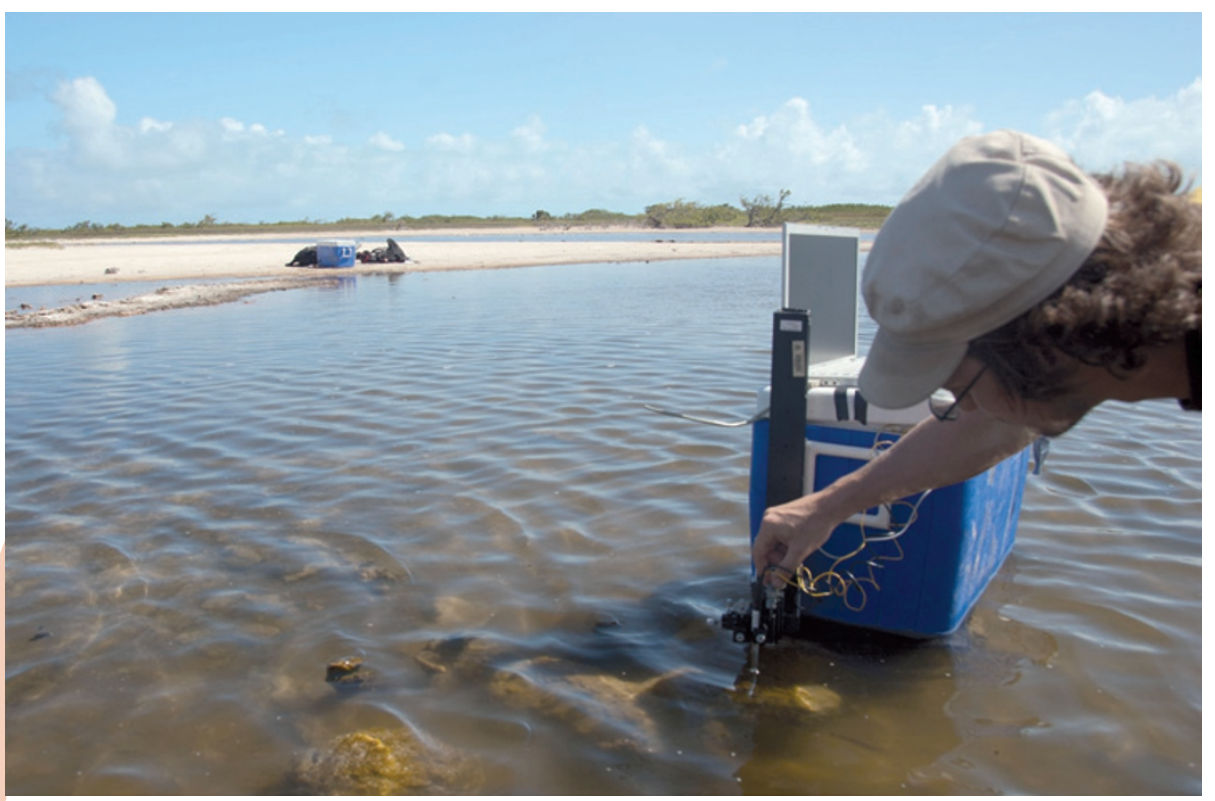

Makeshift floating microsensor, with Stefan Lalonde trying to find ways to keep the device stable while measuring underwater gas profiles.

of organic sludge. We had to use a handheld coring device to penetrate the viscous goo, to access the firm substrate below. The person using the corer had to orient themselves head down in the very buoyant (hypersaline) lagoon waters. A field partner would then push down on the shoulders of their underwater companion, to ensure that enough force was applied to the corer. Underwater gas measurements also proved a challenge: we had to float the electronics on the water's surface in a sealed plastic bin, with a laptop precariously balanced on top. The midday sun would render the LCD screen nearly black at full brightness, and the batteries exhausted quickly as the laptop fans whirred like jet engines. Adding to the discomfort, we had to sit waist-deep in the microbial-mat-filled, sludgy lagoons for what could turn into several hours.

What was the highlight of the work? Finding animals living immediately below the biomats was definitely the highlight. The 'eureka' moment came when one of the co-authors, who was carefully peeling the mat off a sediment sample, found the first creature: a very small worm.

\section{Did you learn anything new?}

We learnt that working in hypersaline lagoons is gooey, and sometimes smelly, but also fun. We worked long hours, but the thrill of even the simplest discovery such as unusual or unexpected animals, beautifully laminated sediment, extrathick biomat or big stromatolites kept us going.

\section{Any ideas for future research projects?} Absolutely. We are now conducting research on the Cambrian and Ediacaran rock record in Uruguay and western Canada, to see how local oxygen oases influenced animal evolution in the Ediacaran. We are also working on new biogeologically significant locales, such as karst lakes in Bacalar, Mexico. The aim of this work is to learn more about animal-biomat-sediment interactions, and to develop a better understanding of their signatures in the geological record.

This is the Backstory to the work by Murray Gingras and colleagues, published on page 372 of this issue. 